\title{
Hubungan Penggunaan Gagdget terhadap Kualitas Tidur Remaja: Literature Review
}

\author{
Wahyu Agung Nugroho' ${ }^{1 *}$, Wiwiek Natalya ${ }^{2}$ \\ ${ }_{1,2}$ Prodi Sarjana Keperawatan, Universitas Muhammadiyah Pekajangan Pekalongan, Indonesia \\ *email: whyuagungn@gmail.com
}

\begin{abstract}
$80 \%$ of the use og gadgets in Indonesia is dominated by teenagers. Teenagers can spend their time just playing with their gadgets. Meanwhile, research data show that $63 \%$ of adolescents have inadequate sleep quality. This study aimed to determine the correlation between gadget use and adolescent sleep quality using a literature review study. Using a literature review design with the PEO (population, exposure, outcame) method ang using five articles from Google Scholar, Pubmed, Proquest published in 2010-2021. It showed that most of the respondents were male (52.42\%) and 13 years old (30,52\%). On the use of gadgets, most respondents were in the category of low use or not addicted (71.97\%). Most of the respondents also had good quality of sleep (75.30\%). The five articles obtained a p-value less than 0,05 . There is a correlation between the use of gadgets with adolescents sleep quality.

Keywords: Adolescents; gadgets; sleep quality
\end{abstract}

\begin{abstract}
Abstrak
Penggunaan gadget di Indonesia $80 \%$ didominasi oleh usia remaja. Remaja bisa menghabiskan waktunya hanya untuk bermain gadget. Sedangkan data penelitian menunjukkan $63 \%$ remaja memiliki kualitas tidur kurang terpenuhi. Penelitian ini bertujuan untuk mengetahui hubungan penggunaan gadget terhadap kualitas tidur remaja menggunakan studi literature review. Menggunakan desain literature review dengan menggunakan metode PEO (population, exposure, outcame) dan menggunakan 5 artikel dari database dengan penelusuran elektronik pada Google Scholar, PubMed, Proquest yang dipublikasikan pada tahun 2010-2021. Karakteristik responden dari kelima artikel didapatkan jumlah responden terbanyak berjenis kelamin laki-laki $(52,42 \%)$, responden terbanyak berusia 13 tahun $(30,52)$. Pad penggunaan gadget sebagian besar responden pada kategori penggunaan rendah atau tidak kecanduan $(71,97 \%)$ dan pada kualitas tidur sebagian besar responden memiliki kualitas yang baik $(75,30 \%)$. Kelima artikel diperoleh hasil $\mathrm{p}$-value < 0,05 . Terdapat hubungan antara penggunaan gadget dengan kualitas tidur remaja.
\end{abstract}

Kata kunci: Gadget, kualitas tidur; remaja

\section{Pendahuluan}

Data di Indonesia menunjukkan bahwa remaja yang menggunakan gadget sangat banyak dengan usia dari 15 samapi 19 tahun dengan persentase sebesar $80 \%$ (Siaran pers Kominfo, 2014). Dimana 30 juta remaja tersebut menggunakan gadget sebagai pilihan utama sebagai alat komunikasi yang mereka gunakan (Keswara, 2019). Dalam penelitian Rini (2020) menunjukkan bahwa 42,4\% remaja telah kecanduan internet yang mana remaja tersebut mengakses internet melalui gadget. Perilaku remaja tersebut menuntut kewaspadaan terhadap kecanduan gadget harus ditingkatkan karena dapat menurunkan kualitas kesehatan remaja (Mawitjere, dkk, 2017). 


\section{Prosiding Seminar Nasional Kesehatan 2021 Lembaga Penelitian dan Pengabdian Masyarakat Universitas Muhammadiyah Pekajangan Pekalongan}

Remaja yang menggunakan gadget akan menghabiskan waktunya hanya untuk bermain gadget termasuk saat mereka di tempat tidur (Hidayat, 2014). Perilaku remaja tersebut dapat berpengaruh terhadap masalah kesehatannya terutama pada kebutuhan istirahat mereka. Studi yang dilakukan Pertiwi (2020) menunjukkan sebanyak $61,2 \%$ remaja sebelum tidur menggunakan smartphonenya lebih dari 35 menit, dan sebanyak 58,8\% remaja mengalami gejala insomnia. Data tersebut meninjukkan sebagian besar remaja mengalami gangguan pada tidurnya yang dipengaruhi dari penggunaan gadget.

Melihat tingginya penggunaan gadget pada remaja dan masalah yang akan ditimbulkan dari kualitas tidur yang buruk, maka peneliti tertarik untuk melakukan penelitian secara literature review untuk mengetahui hubungan dari penggunaan gadget terhadap kualitas tidur remaja.

\section{Metode}

Desain penelitian ini menggunakan lierature review terhadap lima artikel yang didapatkan dengan menggunakan database Google Scholar, Pubmed dan Proquest dengan menggunakan kata kunci. Pemilihan kata kunci dalam penelitian ini mengacu pada PEO. Dalam pencarian artikel memasukkan kaca kunci dengan Bahasa Indonesia dan Bahasa Inggris. Instrumen dalam penelitian ini menggunakan Discren. Pencarian artikel ini dibatasi berdasarkan pada kriteria inklusi yaitu:

1. Populasi penelitian merupakan remaja yang menggunakan gadget.

2. Artikel yang relevan dengan tujuan penelitian.

3. Rentang waktu dalam publikasi artikel 2010-2021.

4. Dalam penulisan artikel menggunakan bahasa Indonesia dan/atau bahasa Inggris.

5. Artikel merupakan artikel asli dan bukan hasil sintesis seperti literature review, systematic review, scooping review, dan sebagainya.

6. Naskah artikel lengkap atau ful/ teks dengan disertakan data pada hasil.

7. Intrumen pengukuran kualitas tidur menggunakan alat ukur PSQI dan KKT.

Sedangkan kriteria eksklusinya yaitu populasi yang diteliti remaja laki-laki atau perempuan saja.

\section{Hasil dan Pembahasan Hasil}

1. Karakteristik responden

a. Karakteristik responden berdasarkan jenis kelamin

Berdasarkan hasil dari literature review dari kelima artikel pada Tabel 3.1, didapatkan jumlah responden berjumlah 3096 responden dengan jumlah responden berjenis kelamin laki-laki lebih banyak dengan jumlah $1623(52,42 \%)$ responden, sedangkan dengan jumlah responden berjenis kelamin perempuan lebih sedikit dengan jumlah 1473 (47,58\%). 


\section{Prosiding Seminar Nasional Kesehatan Lembaga Penelitian dan Pengabdian Masyarakat Universitas Muhammadiyah Pekajangan Pekalongan}

Tabel 3.1 Karakteristik berdasarkan jenis kelamin

\begin{tabular}{|c|c|c|c|c|c|c|c|c|}
\hline \multirow{3}{*}{ No. } & \multicolumn{2}{|l|}{ Artikel } & \multicolumn{4}{|c|}{ Jenis kelamin } & & \\
\hline & \multirow[b]{2}{*}{ Penulis } & \multirow[b]{2}{*}{ Tahun } & \multicolumn{2}{|c|}{ Laki-laki } & \multicolumn{2}{|c|}{ Perempuan } & \multicolumn{2}{|c|}{ Jumlah } \\
\hline & & & $\mathrm{F}$ & $\%$ & $\mathrm{~F}$ & $\%$ & $\mathrm{~F}$ & $\%$ \\
\hline 1. & $\begin{array}{l}\text { Jarmi, A. \& } \\
\text { Rahayuningsih S. I }\end{array}$ & 2017 & 39 & 42,4 & 53 & 57,6 & 92 & 100 \\
\hline 2. & Zou, Y., dkk & 2019 & 1421 & 53,8 & 1218 & 46,2 & 2639 & 100 \\
\hline 3. & Pandey, C. M., dkk & 2019 & 59 & 38,6 & 94 & 61,4 & 153 & 100 \\
\hline 4. & Irfan, Aswar \& Erviana & 2020 & 45 & 45 & 55 & 55 & 100 & 100 \\
\hline 5. & Supartini, Y., dkk. & 2021 & 59 & 52,7 & 53 & 47,3 & 112 & 100 \\
\hline Tota & esponden & & 1623 & 52,42 & 1473 & 47,58 & 3096 & 100 \\
\hline
\end{tabular}

b. Karakteristik responden berdasarkan usia

Berdasarkan hasil analisa kelima artikel didapatkan total responden sebanyak 345 responden, dengan jumlah responden terbanyak pada kategori remaja berusia 13 tahun sebanyak 105 (30,52\%) responden dan responden dengan jumlah yang sedikit berusia 18 tahun sebanyak $1(0,30 \%)$ responden (Tabel 3.2).

Tabel 3.2 Distribusi frekuensi responden berdasarkan usia

\begin{tabular}{|c|c|c|c|c|c|c|c|c|c|c|c|c|}
\hline \multirow{3}{*}{ Usia } & \multicolumn{10}{|c|}{ Penulis } & \multirow{2}{*}{\multicolumn{2}{|c|}{$\begin{array}{l}\text { Jumlah masing- } \\
\text { masing usia }\end{array}$}} \\
\hline & \multicolumn{2}{|c|}{$\begin{array}{l}\text { Jarmi, A. \& } \\
\text { Rahayuningsih } \\
\text { S. I. }\end{array}$} & \multicolumn{2}{|c|}{$\begin{array}{l}\text { Zou, Y., } \\
\text { dkk }\end{array}$} & \multicolumn{2}{|c|}{$\begin{array}{l}\text { Pandey, C. } \\
\text { M., dkk }\end{array}$} & \multicolumn{2}{|c|}{$\begin{array}{l}\text { Irfan, Aswar } \\
\text { \& Erviana }\end{array}$} & \multicolumn{2}{|c|}{$\begin{array}{l}\text { Supartini, } \\
\text { Y., dkk. }\end{array}$} & & \\
\hline & $\mathrm{F}$ & $\%$ & $\mathrm{~F}$ & $\%$ & $\mathrm{~F}$ & $\%$ & $\mathrm{~F}$ & $\%$ & $\mathrm{~F}$ & $\%$ & $\mathrm{~F}$ & $\%$ \\
\hline 12 & 24 & 26,1 & 0 & 0 & 19 & 12,4 & 0 & 0 & 0 & 0 & 43 & 12,5 \\
\hline 13 & 53 & 57,6 & 0 & 0 & 52 & 34,0 & 0 & 0 & 0 & 0 & 105 & 30,52 \\
\hline 14 & 15 & 16,3 & 0 & 0 & 53 & 34,6 & 0 & 0 & 0 & 0 & 68 & 19,77 \\
\hline 15 & 0 & 0 & 0 & 0 & 29 & 19,0 & 13 & 13 & 0 & 0 & 42 & 12,20 \\
\hline 16 & 0 & 0 & 0 & 0 & 0 & 0 & 64 & 64 & 0 & 0 & 64 & 18,60 \\
\hline 17 & 0 & 0 & 0 & 0 & 0 & 0 & 22 & 22 & 0 & 0 & 22 & 6,40 \\
\hline 18 & 0 & 0 & 0 & 0 & 0 & 0 & 1 & 1 & 0 & 0 & 1 & 0,30 \\
\hline $\begin{array}{l}\text { Total } \\
\text { responden }\end{array}$ & 92 & 100 & 0 & 0 & 153 & 100 & 100 & 100 & 0 & 0 & 345 & 100 \\
\hline
\end{tabular}

2. Hasil analisa kualitas tidur remaja

Berdasarkan hasil analisa kelima artikel berdasarkan kualitas tidur didapatkan total responden sebanyak 3096 responden, dimana sebagian besar responden memiliki kualitas tidur yang baik dengan jumlah 2331 (75,30\%) dan sebanyak 765 $(24,70 \%)$ responden memiliki kualitas tidur yang buruk (Tabel 3.3).

Tabel 3.3 Distribusi frekuensi responden berdasarkan kualitas tidur

\begin{tabular}{|c|c|c|c|c|c|c|c|c|}
\hline \multirow{3}{*}{ No. } & \multicolumn{2}{|l|}{ Artikel } & \multicolumn{4}{|c|}{ Kualitas tidur } & & \\
\hline & \multirow[b]{2}{*}{ Penulis } & \multirow[b]{2}{*}{ Tahun } & \multicolumn{2}{|c|}{ Baik } & \multicolumn{2}{|c|}{ Buruk } & \multicolumn{2}{|c|}{ Jumlah } \\
\hline & & & $\mathrm{F}$ & $\%$ & $\mathrm{~F}$ & $\%$ & $\mathrm{~F}$ & $\%$ \\
\hline 1. & $\begin{array}{l}\text { Jarmi, A. \& Rahayuningsih } \\
\text { S. I. }\end{array}$ & 2017 & 43 & 46,7 & 49 & 53,3 & 92 & 100 \\
\hline 2. & Zou, Y., dkk & 2019 & 2121 & 80,4 & 518 & 19,6 & 2639 & 100 \\
\hline 3. & Pandey, C. M., dkk & 2019 & 78 & 51,0 & 75 & 49,0 & 153 & 100 \\
\hline 4. & Irfan, Aswar \& Erviana & 2020 & 56 & 56 & 44 & 44 & 100 & 100 \\
\hline 5. & Supartini, Y., dkk. & 2021 & 33 & 29,5 & 79 & 70,5 & 112 & 100 \\
\hline \multicolumn{3}{|c|}{ Total responden } & 2331 & 75,30 & 765 & 24,70 & 3096 & 100 \\
\hline
\end{tabular}




\section{Prosiding Seminar Nasional Kesehatan Lembaga Penelitian dan Pengabdian Masyarakat Universitas Muhammadiyah Pekajangan Pekalongan}

3. Hasil analisa penggunaan gadget remaja

Berdasarkan hasil analisa kelima artikel berdasarkan penggunaan gadget didapatkan total responden sebanyak 3096 responden. Responden terbanyak merupakan remaja dengan kategori tidak kecanduan (rendah) berjumlah 2228 $(71,97 \%)$, sedangkan pada kategori remaja kecanduan (tinggi) berjumlah 868 (28,03\%) (Tabel 3.4).

Tabel 3.4 Distribusi frekuensi responden berdasarkan penggunaan gadget

\begin{tabular}{|c|c|c|c|c|c|c|c|c|}
\hline \multirow{3}{*}{ No. } & \multicolumn{2}{|l|}{ Artikel } & \multicolumn{4}{|c|}{ Penggunaan gadget } & \multirow{2}{*}{\multicolumn{2}{|c|}{ Jumlah }} \\
\hline & \multirow[t]{2}{*}{ Penulis } & \multirow[t]{2}{*}{ Tahun } & \multicolumn{2}{|c|}{$\begin{array}{l}\text { Tidak kecanduan } \\
\text { (rendah) }\end{array}$} & \multicolumn{2}{|c|}{$\begin{array}{l}\text { Kecanduan } \\
\text { (tinggi) }\end{array}$} & & \\
\hline & & & $\mathrm{F}$ & $\%$ & $\mathrm{~F}$ & $\%$ & $\mathrm{~F}$ & $\%$ \\
\hline 1. & $\begin{array}{l}\text { Jarmi, A. \& } \\
\text { Rahayuningsih S. I. }\end{array}$ & 2017 & 42 & 45,7 & 50 & 54,3 & 92 & 100 \\
\hline 2. & Zou, Y., dkk & 2019 & 2037 & 77,2 & 602 & 22,8 & 2639 & 100 \\
\hline 3. & Pandey, C. M., dkk & 2019 & 61 & 39,9 & 92 & 60,1 & 153 & 100 \\
\hline 4. & Irfan, Aswar \& Erviana & 2020 & 45 & 45 & 55 & 55 & 100 & 100 \\
\hline 5. & Supartini, Y., dkk. & 2021 & 43 & 38,4 & 69 & 61,6 & 112 & 100 \\
\hline Tota & esponden & & 2228 & 71,97 & 868 & 28,03 & 3096 & 100 \\
\hline
\end{tabular}

4. Hubungan penggunaan gadget terhadap kualitas tidur remaja

Berdasarkan dari kelima artikel dimana masing-masing artikel menggunakan uji chi-square dan hasil uji hipotesis dari masing-masing artikel didapatkan $p$-value kurang dari 0,05 (Tabel 3.5).

Tabel 3.5 Hubungan penggunaan gadget terhadap kualitas tidur remaja

\begin{tabular}{|c|c|c|c|c|c|c|c|c|c|}
\hline \multirow{3}{*}{ No. } & \multicolumn{3}{|c|}{ Artikel } & \multicolumn{4}{|c|}{ Kualitas tidur } & \multirow[b]{2}{*}{ Jumlah } & \multirow{3}{*}{$p_{\text {-value }}$} \\
\hline & \multirow{2}{*}{ Penulis } & \multirow[b]{2}{*}{$\begin{array}{l}\text { Uji } \\
\text { hipote. } \\
\text { sis. }\end{array}$} & \multirow{2}{*}{$\begin{array}{c}\text { Renggunaan } \\
\text { gadget }\end{array}$} & \multicolumn{2}{|c|}{ Baik } & \multicolumn{2}{|c|}{ Buruk } & & \\
\hline & & & & $F$ & $\%$ & $F$ & $\%$ & $\%$ & \\
\hline \multirow{3}{*}{1.} & \multirow{3}{*}{$\begin{array}{l}\text { Jarmi, A. \& } \\
\text { Rabaxuningsib } \\
\text { S. I. }\end{array}$} & \multirow{3}{*}{$\begin{array}{l}\text { Chi- } \\
\text { square }\end{array}$} & Rendah & 30 & 71,4 & 12 & 28,6 & 100 & \multirow{3}{*}{0,000} \\
\hline & & & Tinggi & 13 & 26,0 & 37 & 74,0 & 100 & \\
\hline & & & Total & 43 & 46,7 & 49 & 53,3 & 100 & \\
\hline \multirow{3}{*}{2.} & \multirow{3}{*}{ Zou, Y., dkk } & \multirow{3}{*}{$\begin{array}{l}\text { Chi- } \\
\text { square }\end{array}$} & $\begin{array}{l}\text { Tidak } \\
\text { kecanduan }\end{array}$ & 2027 & 95,6 & 10 & 1,9 & 0 & \multirow{3}{*}{0,001} \\
\hline & & & Kecanduan & 94 & 4,4 & 508 & 98,1 & 0 & \\
\hline & & & Total & 2121 & 100 & 518 & 100 & 100 & \\
\hline \multirow{3}{*}{3.} & \multirow{3}{*}{$\begin{array}{l}\text { Pandex, C. M., } \\
\text { dkk }\end{array}$} & \multirow{3}{*}{$\begin{array}{l}\text { Chi- } \\
\text { square }\end{array}$} & $\begin{array}{l}\text { Tidak } \\
\text { kecanduan }\end{array}$ & 48 & 31,4 & 13 & 8,5 & 61 & \multirow{3}{*}{0,000} \\
\hline & & & kecanduan & 30 & 19,6 & 62 & 40,5 & 92 & \\
\hline & & & Total & 43 & 46,7 & 49 & 53,3 & 153 & \\
\hline \multirow{3}{*}{4.} & \multirow{3}{*}{$\begin{array}{l}\text { Infan, Aswar \& } \\
\text { Exwiana. }\end{array}$} & \multirow{3}{*}{$\begin{array}{l}\text { Chi- } \\
\text { square }\end{array}$} & $\begin{array}{l}\text { Tidak } \\
\text { kecanduan }\end{array}$ & 39 & 0 & 6 & 0 & 0 & \multirow{3}{*}{0,000} \\
\hline & & & kecanduan & 17 & 0 & 38 & 0 & 0 & \\
\hline & & & Total & 56 & 0 & 44 & 0 & 100 & \\
\hline \multirow{3}{*}{5.} & \multirow{3}{*}{$\begin{array}{l}\text { Supartini, Y., } \\
\text { dkk. }\end{array}$} & \multirow{3}{*}{$\begin{array}{l}\text { Chi- } \\
\text { square }\end{array}$} & Rendah & 19 & 44,2 & 24 & 55,8 & 38,4 & \multirow{3}{*}{0,007} \\
\hline & & & Tinggi & 14 & 20,3 & 55 & 79,7 & 61,6 & \\
\hline & & & Total & 33 & 29,5 & 79 & 70,5 & 100 & \\
\hline
\end{tabular}




\section{Prosiding Seminar Nasional Kesehatan 2021 Lembaga Penelitian dan Pengabdian Masyarakat Universitas Muhammadiyah Pekajangan Pekalongan}

\section{Pembahasan}

1. Karaktersitik Responden

Berdasarkan analisa data yang telah dilakukan pada kelima artikel didapatkan beberapa karakteristik responden yaitu diantaranya jenis kelamin, usia.

a. Karakteristik responden berdasarkan jenis kelamin

Berdasarkan hasil review kelima artikel pada tabel 4.1, didapatkan jumlah responden berjenis kelamin laki-laki lebih banyak dengan jumlah 1623 (50,2\%) responden dibandingkan dengan jumlah responden berjenis kelamin perempuan. Hal ini sejalan dengan penelitian Supartini, Y, dkk (2021) bahwa mayorits pengguna gadget adalah remaja berjenis kelamin laki-laki (52,7\%). Penelitian Zou, Y., dkk (2019) yang dilakukan pada remaja di Cina juga menunjukkan sebagian besar pengguna gadget adalah remaja berjenis kelamin laki-laki $(53,8 \%)$. Hal ini tidak sejalan dengan dengan penelitian Jarmi, A. \& Rahayuningsih S. I (2017), Pandey, C. M., dkk (2019), Irfan, Aswar \& Erviana (2020) yang menunjukkan sebagian besar pengguna gadget adalah berjenis kelamin perempuan.

Menurut Supartini, Y, dkk (2021) perbedaan ini bisa terjadi dikarenakan perbedaan lokasi pada setiap penelitian yang menyebabkan perbedaan karakteristik responden khususnya pada perbedaan jenis kelamin.

b. Karakteristik berdasarkan usia

Berdasarkan karakteristik responden berdasarkan usia pada tabel 4.2 diketahui responden paling banyak berusia 13 tahun. Hal ini sejalan dengan penelitian Jarmi, A. \& Rahayuningsih S. I. (2017) yang menyatakan mayoritas responden pengguna gadget berusia 13 tahun. Hasil tersebut juga sejalan dengan penelitian Zou, Y., dkk (2019) yang dilakukan pada remaja di Cina yang menunjukkan rata-rata responden berusia 13,18 tahun. Menurut Jarmi, A. \& Rahayuningsih S. I. (2017) remaja pada usia ini mulai diberi kepercayaan untuk memilki gadget, sehingga mereka lebih intens dalam menggunakan gadget.

Remaja usia 13 tahun termasuk ke dalam kategori remaja awal. Remaja pada usia remaja awal memiliki karakteristik minat terhadap kehidupan seharihari, keinginan untuk belajar, dan masih bersikap kanak-kanak, Jarmi, A. \& Rahayuningsih S. I. (2017) juga menjelaskan beberapa karakteristik tersebut dapat menyebabkan adanya perbedaan perspektif terhadap penggunaan gadget antara remaja awal dan remaja akhir. Cara berfikir yang cenderung masih pendek membuat sekelompok remaja awal masih belum memiliki regulasi atau kontrol terhadap dampak buruk yang dapat ditimbulkan dari penggunaan gadget secara berlebihan sehingga memiliki prevalensi yang relatif tinggi (Jarmi, A. \& Rahayuningsih S. I., 2017).

2. Kualitas tidur pada remaja

Kualitas tidur remaja dari hasil review kelima artikel pada tabel 4.3 didapatkan mayoritas responden memiliki kualitas tidur yang baik sebesar 70,30\%. Hasil ini sejalan dengan penelitian Zou, Y., dkk (2019) pada remaja di Cina yang 


\section{Prosiding Seminar Nasional Kesehatan 2021 Lembaga Penelitian dan Pengabdian Masyarakat Universitas Muhammadiyah Pekajangan Pekalongan}

menunjukkan $80,4 \%$ responden memiliki kualitas tidur yang baik. Hal ini tidak sejalan dengan penelitian Supartini, Y., dkk. (2021) yang dilakukan pada remaja di SMP Budi Cendikia Islamic Schoo/ Depok yang menunjukkan bahwa sebagian besar responden memiliki kualitas tidur yang buruk yaitu sebesar 70,5\%. Menurut Supartini, Y., dkk. (2021) perbedaan hasil ini disebabkan oleh karakteristik responden yang berbeda dan faktor lain yang dapat memengaruhi kualitas tidur seseorang. Faktor-faktor tersebut yaitu penyakit, lingkungan, gaya hidup, stres emosional, zat stimulan, diet, merokok, dan motivasi.

\section{Penggunaan gadget pada remaja}

Hasil dari review kelima artikel diperoleh responden dengan penggunaan gadget rendah atau tidak kecanduan memiliki persentase terbanyak yaitu 71,97\%. Hasil ini sejalan dengan penelitian Zou, Y., dkk (2019) yang dilakukan pada remaja di Cina dengan hasil 77,2\% responden tidak kecanduan dengan gadget. Hal ini tidak sejalan dengan beberapa penelitian yang dilakukan pada remaja di Indonesia, seperti pada penelitian Pandey, C. M., dkk (2019) di SMA Negeri 1 Maesaan Kabupaten Minahasa yang menunjukkan $60,1 \%$ responden mengalami kecanduan gadget. Sejalan juga dengan penelitian Supartnii, Y., dkk. (2021) di SMP Budi Cendikia Islamic Schoo/ Depok yang menunjukkan 61,6\% responden menggunakan gadget dalam kategori tinggi atau kecanduan gadget. Hasil tersebut menunjukkan adanya perbedaan penggunaan gadget pada remaja di Cina dan remaja di Indonesia. Perbedaan hasil tersebut bisa disebabkan oleh perbadaan karakteristik di antara responden Zou, Y., dkk (2019).

Menurut Supartini, Y., dkk. (2021) walaupun gadget memiliki berbagai manfaat untuk menunjang kehidupan sekolah pada remaja, namun hal tersebut berpotensi untuk menyebabkan terjadinya kecanduan gadget. Kecanduan gadget sendiri tidak bisa diabaikan karena merupakan masalah kesehatan masyarakat. Dampak negatif bagi kesehatan yang ditimbulkan dari penggunaan gadget yang berlebih diantaranya memicu ketidaknyamanan fisik, seperti sakit kepala $(37,7 \%)$, sakit mata (28,9\%), dan keluhan telinga (42,9\%) (Mushroor, Haque \& Amir, 2019 dalam Supartini, Y., dkk., 2021).

4. Hubungan penggunaan gadget terhadap kualitas tidur remaja

Hasil analisa kelima artikel yang direview menunjukkan terdapat hubungan antara kedua variabel yakni variabel penggunaan gadget dengan variabel kualitas tidur. Diketahui terdapatnya hubungan antara kedua variabel tersebut karena dalam uji hipotesis kelima artikel mendapatkan hasil nilai $\mathrm{p}$-value < dari a $(0,05)$. Hal ini sejalan dengan penelitian Supartini, Y., dkk. (2021) yang menunjukkan hasil signifikan sebesar 0,007 ( $p<0,05)$ yang artinya terdapat hubungan antara kecanduan gadget dengan kualitas tidur remaja, hasil tersebut menunjukkan semakin tinggi penggunaan gadget maka kualitas tidur yang didapatkan akan semakin buruk. Hasil ini juga sejalan dengan penelitian Pandey, C. M., dkk (2019) dari hasil uji chi-squere yang menunjukkan nilai $p=0,000(p=<0,05)$ bahwa terdapat hubungan antara kecanduan gadget dengan kualitas tidur. 


\section{Prosiding Seminar Nasional Kesehatan 2021 Lembaga Penelitian dan Pengabdian Masyarakat Universitas Muhammadiyah Pekajangan Pekalongan}

Gadget bisa dibilang sudah menjadi gaya hidup mereka sehari-hari bahkan remaja tidak bisa hidup dan terlepas dari gadget, sedangkan gaya hidup seseorang sangat berpengaruh terhadap pola tidur seseorang (Irfan, Aswar \& Erviana, 2020). Dapat dilihat dari kebiasaan remaja yang mengisi waktu luangnya untuk bermain gadget untuk aktivitas seperti belanja shop, membuka youtube, instagram, bermain game, dan situs media online lainnya (Irfan, Aswar \& Erviana, 2020).

Jarmi, A. \& Rahayuningsih S. I. (2017) menjelaskan hubungan tersebut bisa terjadi karena pada usia remaja mulai diberi kepercayaan untuk memiliki gadget sendiri dan mulai menunjukkan eksistensi diri dengan menggunakan gadget, oleh karena itu remaja menjadi lebih intens dalam menggunakan gadget. Ditunjukkan pada perilaku remaja yang menggunakan gadget pada malam hari dan sebelum tidur yang membuat remaja menunda waktu tidur dan sulit untuk memulai tidur, hal tersebut dapat mempengaruhi kualias tidurnya. Pendapat tersebut juga diperkuat oleh penelitian Mawitjere (2017) yang menunjukkan bahwa remaja yang menggunakan gadget dalam waktu lama menyebabkan remaja tersebut membutuhkan waktu sekitar 60 menit lebih lama untuk tertidur dari waktu biasanya. Dengan demikian remaja akan cenderung tidur terlamabat dari biasanya dan akan berpengaruh terhadap kualitas tidurnya.

Penggunaan gadget yang berlebihan terutama pada malam hari menunjukkan tingginya kecanduan remaja terhadap gadget maka semakin rendah kualitas tidur pada remaja (Putri, 2018). Secara fisiologis tubuh tidur diatur di pusat otak dibagian RAS (Retikular Activating System) dan BSR ( Bulbar Synchronizing Region). BSR akan aktif ketika kondisi lingkungan kondusif, sedangkan ketika remaja menggunakan gadget maka sistem RAS akan aktif karena mendapat stimulus eksternal seperti cahaya suara dan getaran dari gadget, selanjutnya otak mengimkan sinyal tersebut yang dapat mengaktifkan RAS sehingga menyebabkan remaja tetap terjaga pada malam hari (Jarmi, A. \& Rahayuningsih S. I., 2017).

Pandey, C. M., dkk (2019) menjelaskan perilaku kecanduan penggunaan gadget juga menyebabkan fokus seseorang terpaku pada satu hal yang disenangi seperti ponsel dan waktu untuk tidur digunakan untuk bermain dengan gadget. Remaja yang mengalami kecanduan akan kehilangan waktu yang seharusnya waktu tersebut digunakan untuk tidur sehingga pada keesokan harinya merasa tidak bersemangat, hal ini berdampak pada gangguan kualitas tidur dari yang bersangkutan. Perilaku penggunaan gadget dalam waktu yang lama juga harus diwaspadai karena dapat mengganggu kesehatan dan kehidupan sosial remaja gangguan saraf, mata, telinga, kecanduan, egois, tidak peka terhadap lingkungan gangguan pola tidur (Mawitjere, 2017). Dengan demikian peneliti menyimpulkan bahwa terdapat hubungan antara penggunaan gadget terhadap kualitas tidur remaja.

\section{Kesimpulan}

Dapat disumpulkan dari penelitian literature review kelima artikel yang sudah di review didapatkan karakteristik responden dari kelima artikel yaitu jenis kelamin dan usia. Jenis kelamin responden yang paling banyak yaitu responden dengan jenis 


\section{Prosiding Seminar Nasional Kesehatan 2021 Lembaga Penelitian dan Pengabdian Masyarakat Universitas Muhammadiyah Pekajangan Pekalongan}

kelamin laki-laki sebanyak 1623 responden, sedangkan pada karakteristik berdasarkan usia responden paling banyak berusia 13 tahun sebanyak 105 responden. Berdasarkan kualitas tidur responden dari kelima artikel didapatkan sebagian besar remaja memiliki kualitas tidur yang baik sebanyak 2331 responden. Berdasarkan penggunaan gadget, sebagian besar responden tidak mengalami kecanduan gadget atau dalam penggunaan gadget rendah sebanyak 2228 responden.Terdapat hubungan antara penggunaan gadget dengan kualitas tidur remaja dengan $p$-value kelima artikel $<0,05$.

\section{Referensi}

Hidayat, S.,Mustikasari, "Kecanduan Penggunaan Smartphone dan Kualitas Tidur pada Mahasiswa RIK UI". Fakultas IImu Keperawatan Universitas Indonesia, Kampus UI Depok, Jawa Barat. 2014.

Irfan, Aswar \& Erviana, "Hubungan Smartphone Dengan Kualitas Tidur Remaja Di SMA Negeri 2 Majene". Journal of Islamic Nursing, 5(2), 95-100. 2020.

Jarmi, A., \& Rahayuningsih, S. I., "Hubungan Penggunaan Gadget dengan Kualitas Tidur pada Remaja". Jurnal IImiah Mahasiswa Fakultas Keperawatan, 2(3). 2017.

Keswara, et al., "Perilaku Penggunaan Gadget dengan Kualitas Tidur pada Remaja". Holistik Jurnal Kesehatan, Volume 13, No. 3, 233-239. 2019.

Kominfo. (2014). Siaran Pers Kominfo. Available : https://kominfo.go.id/index.php/content/detail/3980/Kemkominfo\%3A+P engguna+Internet+di+Indonesia+Capai+82+Juta/0/berita_satker

Mawitjere, O. T., et al., "Hubungan Lama Penggunaan Gadget dengan Kejadian Insomnia pada Siswa Siswi di SMA Negeri 1 Kawangkoan". e-journal Keperawatan (e-Kp) Volume 5 Nomor 1. 2017.

Pandey, C. M., Ratag, B. T., \& Langi, F. L., "Hubungan antara kecanduan smartphone dengan kualitas tidur pada siswa SMA Negeri 1 Maesaan Kabupaten Minahasa Selatan". KESMAS, 8(2). 2019.

Pertiwi, H., Alini, A., \& Hidayat, R., "Hubungan Lama Penggunaan Smartphone Sebelum Tidur Dengan Gejala Insomnia Pada Siswa/Siswi Di SMAN 1 Kampar". Jurnal Kesehatan Tambusai, 1(1), 21-27. 2020.

Putri, A. Y., "Hubungan Antara Kecanduan Smartphone Dengan Kualitas Tidur Pada Remaja". Universitas Islam Negeri Sunan Ampel Surabaya. 2018.

Rini, M. K., Titih, H., "Prevalensi dan Dampak Kecanduan Gadget pada Remaja : Literature Review". Jurnal Keperawatan Muhammadiyah 5 (1). Yogyakarta. 2020.

Supartini, Y., Martiana, P. D., \& Sulastri, T., "Dampak Kecanduan Smartphone Terhadap Kualitas Tidur Siswa SMP". JKEP, 6(1), 69-85. 2021.

Zou, Y., Xia, N., Zou, Y., Chen, Z., \& Wen, Y., "Smartphone addiction may be associated with adolescent hypertension: a cross-sectional study among junior school students in China". BMC pediatrics, 19(1), 1-8. 2019. 